\title{
Risk Factors Associated with Dysfunction of Permanent Tunneled Cuffed Hemodialysis Catheters; Single Center Experience
}

\author{
Işıl Yıldız' iD
}

${ }^{1}$ Acibadem University Atakent Hospital Department of Radiology, Istanbul,Turkey

Işı| YILDIZ, Dr. Öğr. Üyesi

Correspondence: |şı| YIIIIz Acibadem University Atakent Hospital Department of Radiology, Istanbul,Turkey Phone: +905323560244 E-mail:drisilyildiz@gmail.com

$\begin{array}{ll}\text { Received } & : 23 \text { February } 2021 \\ \text { Accepted } & : 16 \text { May } 2021\end{array}$

\section{ABSTRACT}

Purpose: Permanent tunneled cuffed catheters are frequently preferred for hemodialysis in patients with chronic renal failure (CRF), but the factors associated with the dysfunction of these catheters are not well known. Our goal is to investigate these risk factors.

Materials and Methods: All cases with a diagnosis of CRF and a permanent tunneled cuffed catheter inserted into the central vein for the first time in our radiology clinic between 2014 and 2019 and who developed catheter dysfunction were included in the study. Demographic and clinical data of the cases were obtained from file records. The relationship between the causes of catheter dysfunction and the presence of diabetes and hypertension was investigated.

Results: Of the total 123 cases, 78 (63.4\%) were male, 45 (36.6\%) were female, the median age was 55 (28-78). Twenty-nine (23.6\%) of the cases had thrombosis, 72 (58.5\%) had venous stenosis and 22 (17.9\%) had catheter dysfunction due to fibrin sheath. Dysfunction groups were compared with each other in terms of age, gender, duration of operation of the catheter, CRF etiology, comorbid diseases, the vein where the catheter was placed and the use of anticoagulants. The most important cause of catheter dysfunction in the early period was thrombosis $(p=0.003)$. When the causes of dysfunction were examined, the most common causes of dysfunction were venous stenosis in patients with hypertension, thrombosis in patients with diabetes as a concomitant disease without diabetes in the etiology of (RF, and thrombosis in patients with diabetes in CRF etiology $(p<0.001)$. In addition, it was found that catheter dysfunction due to thrombosis developed less in patients using anticoagulants $(p<0.001)$. There was no statistically significant difference between the groups in terms of other parameters $(p>0.05)$.

Conclusion: The use of low-dose anticoagulants plays a protective role against thrombosis. The use of low-dose anticoagulants in patients without contraindications, especially in diabetic patients, may reduce especially early catheter dysfunction.

Keywords: Fibrin, hemodialysis, permanent tunneled cuffed hemodialysis catheter, stenosis, thrombosis

Kalııı Tünelli Hemodiyaliz Kateter Disfonksiyonu ile İlişkili Risk Faktörleri; Tek Merkez Deneyimi

ÖZET

Amaç: Kronik böbrek yetmezliği (KBY) olan hastalarda hemodiyaliz için kalıcı tünelli kaflı kateterler sık tercih edilmektedir, ancak bu kateterlerin disfonksiyonu ile ilişkili risk faktörleri yeterince bilinmemektedir. Amacımız bu risk faktörlerini araştırmak.

Gereçve Yöntem: Çalışmaya, KBY tanısı ile 2014-2019 yilları arasında hastanemiz Radyoloji kliniğinde, santral vene ilk defa kalııı tünelli kateter yerleştirilmiş ve izlemde kateter disfonksiyonu gelişmiş tüm hastalar dahil edildi. Hastaların demografik ve klinik verileri dosya kayıtlarından elde edildi. Kateter disfonksiyon nedenleri ile diyabet ve hipertansiyon varlığı arasındaki ilişki karşılaştırııdı.

Bulgular: Toplam 123 hastanın 63'ü $(\% 63,4)$ erkek ve medyan yaş $55(28-78)$ yıl saptandı. Hastaların $29^{\prime}$ unda $(\% 23,6)$ tromboz, 72 'sinde $(\% 58,5)$ venöz stenoz ve 22 'sinde $(\% 17,9)$ fibrin kllffina bağlı kateter disfonksiyonu gelişti. Disfonksiyon grupları birbiriyle yaş, cinsiyet, kateterin çalışma süresi, KBY etiyolojisi, komorbid hastalıklar, kateterin yerleştirildiği ven ve antikoagülan kullanımı açııından karşılaştırıldı. Tromboz erken döenemde gelişen disfonksiyonun en önemli nedeni idi. Hipertansiyonu olan hastalarda en önemli disfonksiyon nedeninin venöz stenoz, KBY etiyolojisinde diyabeti olanlarda ve KBY'ne eşlik eden diyabeti olanlarda ise en önemli tromboz nedeninin tromboz olduğu görüldü $(p<0,001)$. Ayrıca antikoagülan kullanan hastalarda tromboza bağıl kateter disfonksiyonu daha nadir geliştiği saptandı $(p<0,001)$. Diğer parametreler açısından gruplar arasında istatistiksel fark saptanmadı $(p>0,05)$.

Sonuç: Diyabet ve hipertansiyon kateter disfonksiyonu için risk faktörüyken, düşük doz antikoagülan kullanımı tromboza karşı koruyucu rol oynamaktadır. Tansiyon ve diyabet kontrol altında tutularak, kontrendikasyonu olmayan hastalara düşük doz antikoagülan verilerek kateter disfonksiyonu azaltılabilir.

Anahtar kelimeler: fibrin, kalıc tünelli hemodiyaliz kateteri, stenoz, tromboz 
F or patients with chronic renal failure (CRF), arteriovenous fistulas or arteriovenous grafts are preferred for long-term hemodialysis due to the low possibility of infection and high possibilty of long-term use. However, hemodialysis with a permanent tunnel cuffed catheter is recommended for elderly patients who are in the process of arteriovenous fistula and arteriovenous graft maturation, are waiting for renal transplantation, and have high risk associated with diabetes and cardiovascular diseases $(1,2)$. In addition, permanent tunneled cuffed catheters are preferred if arteriovenous fistula may cause an increase in the symptoms of underlying heart diseases or respiratory failure $(3,4)$. According to the Kidney Disease Outcomes Quality Initiative, if a temporary catheter is required for more than 3 weeks, if an arteriovenous fistula cannot be opened and life expectancy is short, a permanent tunnel cuffed catheter is recommended (5). Although tunneled cuffed catheters can be placed in many central veins, the internal jugular vein is most frequently preferred (6). Tunneled cuffed hemodialysis catheters have advantages such as easy placement, low damage to the vascular endothelium due to their soft structure, and low cause for intravascular coagulation, but it is known that various problems such as thrombosis, infection, fibrin sheath formation and central venous stenosis develop due to these catheters (2). Numerous studies have reported that the morbidity and mortality of hemodialysis patients that are associated with the central venous route used for hemodialysis, but few studies have reported risk factors associated with permanent tunneled hemodialysis catheter dysfunction. In this study, the relationship between the cause of catheter dysfunction and the presence of CRF, diabetes, and hypertension in CRF patients with a permanent tunneled cuffed hemodialysis catheter was investigated.

\section{Materials and Methods}

This study was conducted cross-sectionally and retrospectively. A retrospective analysis of 513 cases with a diagnosis of CRF and in whom a permanent tunneled cuffed hemodialysis catheter was placed in the interventional radiology clinic of our hospital between 2014 and 2019. Cases with catheter dysfunction during follow-up were included in the study. Cases with the same central vein previously catheterized with a permanent or temporary catheter were not included in the study.

Digital records of a total of 123 cases who met the inclusion criteria were examined, some of the patients were contacted by phone and information was obtained. Age, gender, follow-up time, duration of catheter operation, comorbid diseases, CRF etiology, use of anticoagulants unrelated to catheter use and causes of catheter dysfunction were recorded.

The relationship between the causes of catheter dysfunction and possible risk factors for catheter dysfunction was examined.

A hemodialysis catheter was placed in all cases included in the study by the same interventional radiologist. Central veins were evaluated with gray scale and duplex ultrasound before catheterization. After the necessary sterilization was provided, local anesthesia (2\% lidocaine) was applied to the procedure area. The jugular vein was catheterized using the modified Seldinger technique. The length of the tunnel that needs to be formed was determined by making necessary measurements for each patient. Following local anesthesia, the catheter tunnel was opened over the pectoral fascia. The tunneled cuffed catheter can be advanced into the central vein through the peel away sheath. The tunneled cuffed catheter was positioned so that its distal tip remained distal to the superior vena cava.

A 14.5 French carbothane permanent tunnel cuffed hemodialysis catheter (Covidien, Mansfield, MA, USA) was used in all cases. A $24 \mathrm{~cm}$ long catheter was inserted through the right jugular vein and a $28 \mathrm{~cm}$ long catheter was inserted through the left jugular vein.

If the hemodialysis blood pump rate is lower than $300 \mathrm{~mL}$ / min, it was considered as catheter dysfunction (7). All of the catheters with dysfunction were evaluated angiographically by injection of contrast media.

SPSS 26.0 and Modeler 18.1 (IBM Corporation, Armonk, New York, United States) programs were used in the analysis of variables. The conformity of univariate data to normal distribution was evaluated by Kolmogorov-Smirnov test and Shapiro-Wilk francia test, while variance homogeneity was evaluated with Levene test. Quantitative variables are mean \pm SD in tables. (standard deviation) and Median (Percentile 25\% / Percentile 75\%), while categorical variables were shown as $\mathrm{n}(\%)$. Variables were analyzed at a $95 \%$ confidence level and a $p$ value of less than 0.05 was considered significant. 


\section{Results}

Of the total 123 cases, 78 (63.4\%) were male, 45 (36.6\%) were female, and the median age was 55 (28-78) years. The mean follow-up period was $24.5 \pm 5.6$ months, and the mean working time of the permanent tunnel cuffed catheter was $16.7 \pm 12.0$ months. The right jugular vein was used for access in $86(69.9 \%)$ of the cases, and the left jugular vein in 37 (30.1\%). During follow-up thrombosis developed in 29 (23.6\%) of the cases, central venous stenosis in $72(58.5 \%)$, and catheter dysfunction due to fibrin sheath in 22 (17.9\%). Diabetes in 20 (16.3\%), hypertension in $12(9.8 \%)$, both diseases in $6(4.9 \%)$, and chronic polycystic kidney disease in 26 (21.1\%) patients. Etiology of 59 (48\%) patients could not be determined. 35 (28.5\%) of the cases had diabetes, 43 (35\%) had hypertension, and 38 (30.9\%) had both comorbid diseases. The Mann Whitney $\mathrm{u}$ Test was tested using Monte Carlo simulation results in the comparison of thrombosis, stenosis, and fibrin sheath groups individually and without group discrimination according to gender and duration of catheter occlusion variables (Table 1).

\begin{tabular}{|c|c|}
\hline Age (years)* & $55(28-78)$ \\
\hline \multicolumn{2}{|l|}{ Gender, n (\%) } \\
\hline Male & $78(\% 63,4)$ \\
\hline Female & $45(36,6)$ \\
\hline Follow-up period (months) ${ }^{* *}$ & $24,5 \pm 5,6$ \\
\hline Patency (months) ${ }^{* *}$ & $16,7 \pm 12,0$ \\
\hline \multicolumn{2}{|l|}{ CRF Etiology, n(\%) } \\
\hline Diabetes & $20(16,3)$ \\
\hline Hypertension & $12(9,8)$ \\
\hline Hypertension and diabetes & $6(4,9)$ \\
\hline Polycystic kidney disease & $26(21,1)$ \\
\hline Unknown & $59(48)$ \\
\hline \multicolumn{2}{|l|}{ Comorbidities, n (\%) } \\
\hline Diabetes & $35(28,5)$ \\
\hline Hypertension & $43(35)$ \\
\hline Hypertension and diabetes & $38(30,9)$ \\
\hline No comorbidity & $7(5,7)$ \\
\hline \multicolumn{2}{|l|}{ Access vein $\mathrm{n}(\%)$} \\
\hline Right jugular vein & $86(69,9)$ \\
\hline Left jugular vein & $37(30,1)$ \\
\hline On anticogulants, n(\%) & $100(81,3)$ \\
\hline \multicolumn{2}{|c|}{ Cause of catheter dysfuction, n(\%) } \\
\hline Thrombosis & $29(23,6)$ \\
\hline Stenosis & $72(58,5)$ \\
\hline Fibrin sheath & $22(17,9)$ \\
\hline
\end{tabular}

The median value of the patency of the catheters in diabetic patients was 15 months and 16 months in hypertensive patients. The median value of catheter patency in patients with diabetes and hypertension was 9 months. The median values of patency in patients with only diabetes or hypertension were statistically significantly higher than the median value of catheter patency in patients with both diabetes and hypertension $(p=0.020, p=0.019$, respectively). There was no statistically significant difference between the median values of patency of catheters in diabetic patients ( 15 months) and the median values of patency of catheters in patients with hypertension (16 months) ( $p=0.901)$. The Kruskal-Wallis H Test was used with Monte Carlo simulation technique results for the comparison of thrombosis, stenosis and fibrin sheath groups according to comorbid diseases and occlusion time variables separately and without group discrimination, and Dunn's Test was used for Post Hoc analyzes (Table 2).

No significant difference was found between the patency of the catheters between men and women $(P=0.062)$. No statistically significant difference was found between the patency of the permanent cuffed tunnel catheters inserted with the right jugular vein access and the permanent cuffed tunnel catheters inserted with the left jugular vein access $(p=0.234)$. Pearson Chi-Square test was used to compare thrombosis, stenosis, and fibrin sheath groups according to gender and categorical variables of the catheter placed vein.

Each case group that developed thrombosis, stenosis and catheter dysfunction due to fibrin sheath was compared with the other case groups in terms of age, gender, CRF etiology, comorbid diseases, the vein in which the catheter was placed, and the use of anticoagulants. It was found that catheter dysfunction in the early period mostly developed due to thrombosis $(p=0.003)$. It was determined that the most important cause of catheter dysfunction was thrombosis in patients with comorbid diabetes, and central vein stenosis was the most important cause of dysfunction in patients with hypertension $(p<0.001)$. It was found that catheter thrombosis developed more frequently in patients whose chronic renal failure etiology is diabetes when compared with both central venous stenosis and fibrin sheath groups $(p<0.001)$. In addition, it was found that catheter dysfunction due to thrombosis was less common in patients using anticoagulants $(p<0.001)$. There was no statistical difference between the groups in terms of other parameters $(p>0.05)$ (Table 3 ). 


\begin{tabular}{|c|c|c|c|c|c|c|c|c|}
\hline & \multicolumn{2}{|r|}{ Thrombosis } & \multicolumn{2}{|r|}{ Stenosis } & \multicolumn{2}{|r|}{ Fibrin sheath } & \multicolumn{2}{|r|}{ Total } \\
\hline & $\mathrm{n}$ & Median (Q1 / Q3) & $\mathrm{n}$ & Median (Q1 / Q3) & $\mathrm{n}$ & Median (Q1 / Q3) & $\mathrm{n}$ & Median (Q1 / Q3) \\
\hline \multicolumn{9}{|l|}{ Gender } \\
\hline Female & 7 & $10(5 / 28)$ & 31 & $18(8 / 21)$ & 7 & $20(9 / 32)$ & 45 & $18(8 / 21)$ \\
\hline Male & 22 & $8(4 / 14)$ & 41 & $14(10 / 18)$ & 15 & $21(12$ / 33) & 78 & $13(8 / 21)$ \\
\hline$P$ value & & $0.243^{u}$ & & $0.394^{\mathrm{u}}$ & & $0.581^{\text {u }}$ & & $0.236^{u}$ \\
\hline \multicolumn{9}{|l|}{ Access Vein } \\
\hline Right jugular vein & 18 & $8.5(4 / 15)$ & 51 & $15(9 / 19)$ & 17 & $21(13 / 32)$ & 86 & $14.5(9 / 21)$ \\
\hline Left jugular vein & 11 & $8(5 / 15)$ & 21 & $16(9 / 22)$ & 5 & $20(12 / 21)$ & 37 & $12(8 / 21)$ \\
\hline$P$ value & & $0.992^{\text {u }}$ & & $0.944^{u}$ & & $0.406^{u}$ & & $0.550^{u}$ \\
\hline \multicolumn{9}{|l|}{ Comorbidities } \\
\hline Diabetes (A) & 12 & $9.5(7 / 14)$ & 15 & $18(12$ / 23) & 8 & $22.5(18.5$ / 29) & 35 & $15(9 / 23)$ \\
\hline Hypertension (B) & 5 & $15(11$ / 36) & 33 & $16(10$ / 19) & 5 & $16(13 / 22)$ & 43 & $16(10 / 21)$ \\
\hline $\mathrm{DM}+\mathrm{HT}$ & 12 & $4.5(3 / 13)$ & 22 & $11.5(8 / 18)$ & 4 & 9.5 (7 / 21.5) & 38 & $9(6 / 18)$ \\
\hline$P$ value & & $0.062^{\mathrm{kw}}$ & & $0.234 \mathrm{kw}$ & & $0.421 \mathrm{kw}$ & & $0.026^{\mathrm{kw}}$ \\
\hline \multirow{3}{*}{ Pairwise comparation } & $A->B$ & ns. & & ns. & & ns. & & 0.901 \\
\hline & $A->C$ & ns. & & ns. & & ns. & & 0.020 \\
\hline & $B->C$ & ns. & & ns. & & ns. & & 0.019 \\
\hline
\end{tabular}

\begin{tabular}{|c|c|c|c|c|}
\hline & $\begin{array}{c}\text { Thrombosis, } \\
n=29\end{array}$ & $\begin{array}{c}\text { Stenosis, } \\
\mathrm{n}=72\end{array}$ & $\begin{array}{c}\text { Fibrin sheath } \\
\quad n=22\end{array}$ & $\mathrm{p}$ \\
\hline \multicolumn{5}{|l|}{ Gender, n(\%) } \\
\hline Male & $22(75,9)$ & $41(56,9)$ & $15(68,2)$ & \multirow{2}{*}{0,193} \\
\hline Female & $7(24,1)$ & $31(43,1)$ & $7(31,8)$ & \\
\hline $\mathrm{Age}^{* *}$ & $54,7 \pm 11,6$ & $55,1 \pm 11,1$ & $52,4 \pm 9,7$ & 0,575 \\
\hline Patency* & $8(5-15)$ & $15(9-19,5)^{\text {a }}$ & $20,5(12-32)^{a}$ & 0,003 \\
\hline \multicolumn{5}{|l|}{ Comorbidities, n(\%) } \\
\hline Diabetes+ hypertension & $12(41,4)$ & $22(30,6)$ & $4(18,2)$ & \multirow{4}{*}{$<0,001$} \\
\hline Hypertension & $5(17,2)$ & $33(45,8)^{a}$ & $5(22,7)$ & \\
\hline Diabetes & $12(41,4)^{b}$ & $15(20,8)$ & $8(36,4)$ & \\
\hline No Comorbidities & $0(0,0)$ & $2(2,8)$ & $5(22,7)^{\mathrm{ab}}$ & \\
\hline \multicolumn{5}{|l|}{ Etiology of CRF, n(\%) } \\
\hline Others & $4(13,8)$ & $41(56,9)^{a}$ & $14(63,6)^{a}$ & \multirow{5}{*}{$<0,001$} \\
\hline Hypertension & $4(13,8)$ & $7(9,7)$ & $0(0,0)$ & \\
\hline Diabetes & $11(37,9)^{\mathrm{bc}}$ & $7(9,7)$ & $0(0,0)$ & \\
\hline Diabetes+ hypertension & $7(24,1)^{b}$ & $1(1,4)$ & $1(4,5)$ & \\
\hline Polycystic kidney & $3(10,3)$ & $16(22,2)$ & $7(31,8)$ & \\
\hline \multicolumn{5}{|l|}{ Access vein, $\mathrm{n}(\%)$} \\
\hline Right jugular vein & $68(62,1)$ & $51(70,8)$ & $17(77,3)$ & \multirow{2}{*}{0,519} \\
\hline Left jugular vein & $11(37,9)$ & $21(29,2)$ & $5(22,7)$ & \\
\hline Anticoagulan, n(\%) & $7(24,1)$ & $71(98,6)^{a}$ & $22(100,0)^{a}$ & $<0,001$ \\
\hline
\end{tabular}


One-Way Anova (Robust Test: Brown-Forsythe) test, one of the parametric methods, was used to compare thrombosis, stenosis and fibrin sheath groups with each other according to their age, while the Kruskal-Wallis H Test, one of the nonparametric tests, was used with the results of the Monte Carlo simulation technique, and the Post Hoc analysis.

In our study, we found that early catheter dysfunction was associated with the presence of diabetes in the etiology of CRF, and the presence of diabetes and hypertension among comorbid diseases in patients with permanent tunneled cuffed catheters for hemodialysis. The most important cause of catheter dysfunction in the early period was thrombosis and it was found that thrombosis-related catheter dysfunction developed less frequently in patients using low-dose anticoagulants. In the comparison of comorbid disease, CRF etiology, and anticoagulant use according to categorical variables, the Fisher-FreemanHolton test was tested using the Monte Carlo Simulation technique, and the column ratios for significant variables were compared with each other and expressed according to the Benjamini-Hochberg corrected $p$ value results.

In order to predict the causes of catheter dysfunction, variables that are significant in Table 2 (Anticoagulant use, catheter working time, comorbid diseases and CRF etiology.) were included in the independent model in Neural Network (Multilayer Perceptron) analysis. According to this model, the rate of accurately predicting thrombosis was $86.2 \%$, stenosis $90.3 \%$, fibrin sheath $40.9 \%$, and overall correct prediction rate $80.5 \%$. The significance rates of the variables were determined as $100 \%$ anticoagulant use, $61.6 \%$ catheter working time, $49.2 \%$ comorbid diseases and $40.8 \%$ renal disease etiology, respectively.

\section{Discussion}

Various risk factors associated with tunneled cuffed catheter dysfunction have been reported in the literature (8). One of these risk factors is related to the central vein where the catheter will be placed through. In many studies, it has been reported that jugular vein catheters remain patent longer than other central veins (9). In the study of Engstrom Bl, et al. (10), it was reported that catheters which has access from right jugular vein were patent longer than the left jugular vein catheters. In our study, the catheter was used in all cases with right or left jugular vein access. Unlike the literature, there was no significant difference between the type of catheter dysfunction and the patency. We think that the reason for this is that the follow-up periods in our study were shorter compared to these studies. In the study of Shingarev, et al. (11) it was reported that only $34 \%$ of tunnel cuffed catheters has central vein access for the first time worked at the end of the first year Shi M, et al. (12) reported that $82 \%$ of the catheters which have central venous access were patent for 1 year and the median patency was 45 months. In another similar study, it was reported that $74.5 \%$ of the catheters were patent end of the first (13). In our study, similar to the literature, $56 \%$ of the catheters were patent at the end of the first year and the average patency was 16.7 months.

In the study of Shi M ,et al (12), $6.9 \%$ of the cases with tunneled cuffed catheter dysfunction was caused by infection, $51.7 \%$ by thrombus formation, $27.6 \%$ by central vein stenosis, and $13.8 \%$ by fibrin sheath. In the study of Ponce D, et al. (14), it was reported that dysfunction developed mostly due to thrombosis at a rate of $45 \%$. Unlike the literature, central venous stenosis was the most common cause of catheter dysfunction (58.5\%) in our study. We think that dysfunction due to thrombosis developed less because most of our patients used low-dose anticoagulants for various reasons. In the literature, conflicting results have been reported about the relationship between the presence of polycystic kidney disease in advanced age, gender and CRF etiology and the development of catheter dysfunction (15). In the study of Shi M, et al. (12) advanced age was reported to be a risk factor for catheter dysfunction. In the study of Szarnecka-Sojda A, et al. (16) it was reported that there was a relationship between gender and catheter dysfunction. In the study of Fox J, et al. (17), it was reported that there was a relationship between polycystic kidney disease and catheter dysfunction. In our study, no relationship was found between the development of catheter dysfunction and the presence of polycystic kidney disease in advanced age, gender and CRF etiology. This may be due to the relatively short follow-up time of our study. In the study of Valliant AM, et al. (18) diabetes was reported to be a risk factor for catheter dysfunction. In another study uncontrolled diabetes was reported to be a risk factor for catheter thrombosis (19). In our study, it was determined that the presence of diabetes in the etiology of CRF or as a comorbid disease is a risk factor for catheter thrombosis, similar to the literature. In addition, it was determined that catheter dysfunction due to thrombosis developed in the early period compared to other causes of dysfunction. In other words, diabetes was found to be a risk factor for early dysfunction. 
Studies have reported that stenosis developed in catheterized central veins due to trauma (20). In addition, it has been reported that central vein stenosis is mostly seen in patients who are catheterized for short-term hemodialysis (21). In our study, hypertension was determined as a risk factor for early catheter dysfunction due to central venous stenosis. The reason for this has been interpreted as hypertension increases vascular trauma possibility. Similar to the literature, in our study, contrast-enhanced angiographic evaluation was performed in all cases with catheter dysfunction, and it was found that $17.9 \%$ of the cases developed catheter dysfunction due to the fibrin sheath. Studies have reported that the use of low-dose aspirin and warfarin reduces catheter thrombosis (23). In a study, it was reported that low-dose warfarin use decreased the frequency of thrombosis from $38 \%$ to $10 \%$ in patients with central venous catheter receiving chemotherapy (24). In our study, it was found that catheter dysfunction due to thrombosis was less common in patients using low-dose anticoagulants in accordance with the literature. The first limitation of our study is that it is a retrospective study, and the second limitation is that we could not give the results of different applications because catheterization was performed by the same interventional radiologist in a single center. We believe that these limitations of our study will not change the results we found.

\section{Conclusion}

While diabetes and hypertension are risk factors for tunneled cuffed catheter dysfunction, the use of low-dose anticoagulants plays a protective role in catheter thrombosis. Among patients who are catheterized with tunneled cuffed catheters, the use of low-dose anticoagulants may be effective in preventing thrombosis and early dysfunction in patients with no contraindications.

\section{References}

1. Peter R and Bream PR Jr. Update on insertion and complications of central venous catheters for hemodialysis. Semin Intervent Radiol. 2016;33:31-8. DOI:10.1055/s-0036-1572547

2. Quarello F, Forneris G, Borca M, et al. Do central venous catheters have advantages over arteriovenous fistulas or grafts? J Nephrol. 2006;19:265-79.

3. Labriola $L$ and Pochet JM. Any use for alternative lock solutions in the prevention of catheter-related blood stream infections? J Vasc Access. 2017;18:S34-8. DOI: 10.5301/jva.5000681

4. Ibeas-Lopez, J. New technology: Heparin and antimicrobial-coated catheters. J Vasc Access. 2015;S16:48-53. DOI:10.5301/jva.5000376

5. Lok C, Huber T, Lee T, et al. KDOQI Clinical Practice Guidelines for Vascular Access: 2019 Update. Am J Kidney Dis. 2020;75:S1-164. DOI:10.1053/j.ajkd.2019.12.001

6. Timsit JF. What is the best site for central venous catheter insertion in critically ill patients? Crit Care. 2003;7:397-9. DOI:10.1186/cc2179
7. Kelber J, Delmez JA and Windus DW. Factors affecting delivery of high-efficiency dialysis using temporary vascular access. Am J Kidney Dis. 1993;22:24-9. DOI:10.1016/s0272-6386(12)70162-2

8. Rathi M, Pinnamaneni VST and Sakhuja V. Non-imaging assisted insertion of un-cuffed, non-tunneled internal jugular venous catheters for hemodialysis: Safety and utility in modern day world. Biomed J. 2016;39:283-8. DOI:10.1016/j.bj.2015.12.004

9. Maya ID and Allon M. Outcomes of tunneled femoral hemodialysis catheters: Comparison with internal jugular vein catheters. Kidney Int. 2015;68:2886-9. DOI: 10.1111/j.1523-1755.2005.00762.x

10. Engstrom $\mathrm{BI}$, Horvath JJ, Stewart JK, et al. Tunneled internal jugular hemodialysis catheters: Impact of laterality and tip position on catheter dysfunction and infection rates. J Vasc Interv Radiol. 2013;24:1295-1302. DOI:10.1016/j.jvir.2013.05.035

11. Shingarev R, Barker-Finkel $J$ and Allon M. Natural history of tunneled dialysis catheters placed for hemodialysis initiation. J Vasc Interv Radiol. 2013;24:1289-94. DOI:10.1016/j.jvir.2013.05.034

12. Shi M, CuiT, Ma L, et al. Catheter failure and mortality in hemodialysis patients with tunneled cuffed venous catheters in a single center. Blood Purif. 2017;43:321-6. DOI: 10.1159/000455062

13. Coentrao L, Santos-Araujo C, Dias C, et al. Effects of starting hemodialysis with an arteriovenous fistula or central venous catheter compared with peritoneal dialysis: A retrospective cohort study. BMC Nephrol. 2012;13:88. DOI: 10.1186/1471-2369-13-88

14. Ponce $D$, Mendes $M$, Silva $T$, et.al. Occluded tunneled venous catheter in hemodialysis patients: Risk factors and efficacy of alteplase. Artif Organs. 2015;39:741-7. DOI:10.1111/aor.12462

15. Wang $K$, Wang $P$, Liang $X$, et.al. Epidemiology of haemodialysis catheter complications: A survey of 865 dialysis patients from 14 haemodialysis centres in Henan province in China. BMJ Open. 2015;5:e007136. DOI:10.1136/bmjopen-2014-007136

16. Szarnecka-Sojda A, Jacheć W, Polewczyk $M$, et.al. Risk of complications and survival of patients dialyzed with permanent catheters. Medicina (Kaunas). 2019;56:2. DOI:10.3390/ medicina56010002

17. Fox J, Joubert $G$ and Loggenberg E. Tunnelled haemodialysis catheters in central free state: Epidemiology and complications. SA J Radiol. 2019;23:1791. DOI:10.4102/sajr.v23i1.1791

18. Valliant AM, Chaudhry MK, Yevzlin AS, et.al: Tunneled dialysis catheter exchange with fibrin sheath disruption is not associated with increased rate of bacteremia. J Vasc Access. 2015;16:52-6. DOI:10.5301/jva.5000301

19. Vats HS. Complications of catheters: Tunneled and non-tunneled. Adv Chronic Kidney Dis. 2012;19:188-94. DOI: 10.1053/j. ackd.2012.04.004

20. Campean V, Neureiter D, Varga I, et al. Atherosclerosis and vascular calcification in chronic renal failure. Kidney Blood Press Res. 2005;28:280-9. DOI:10.1159/000090182

21. Afzal A, Ulhaq AU, Ahmed A, et al. Hemodialysis patients; Central vein stenosis following temporary double lumen catheterization in internal jugular and subclavian veins. The Prof Med J. 2017;24:8

22. Schon D and Whittman D. Managing the complications of longterm tunneled dialysis catheters. Semin Dial. 2003;16:314-22. DOI: 10.1046/j.1525-139x.2003.16060.x

23. Rackoff WR, Weiman $M$, Jakobowski $D$, et al. A randomised, controlled trial of the efficacy of a heparin and vancomycin solution in preventing central venous catheter infections in children. J Pediatr. 1995;127:147-51. DOI:10.1016/s0022-3476(95)70276-8

24. Bern MM, Lokich JJ, Wallach SR, et al. Very low doses of warfarin can prevent thrombosis in central vein catheters. Ann Intern Med. 1990;112:423-8. DOI:10.7326/0003-4819-76-3-112-6-423 